\title{
Measuring the impact of regional export promotion: The Spanish case
}

\author{
Salvador Gil ${ }^{1}$, Rafael Llorca ${ }^{1}$, José A. Martínez Serrano ${ }^{1}$ \\ ${ }^{1}$ Facultad de Economía, Departamento de Estructura Económica, Universidad de Valencia, Av de los Naranjos s/n, \\ 46022 Valencia, Spain (e-mail: salvador.gil-pareja@uv.es, rafael.1lorca@uv.es,jams@uv.es)
}

Received: 15 July 2006 / Accepted: 19 February 2007

\begin{abstract}
This article estimates the effect of Spanish regional trade agencies abroad on exports using the gravity model. The results indicate that regional agencies increase trade. The estimated impact seems to be larger than that of Spanish embassies and consulates. Moreover, a disaggregated analysis shows that this effect is not evenly distributed across Spanish regions.
\end{abstract}

JEL classification: $F 14$, R12

Key words: Export, foreign trade agencies, gravity equation, Spanish regions

\section{Introduction}

Several Spanish regional governments have established a network of offices abroad with the aim of providing support for companies wishing to trade and invest in foreign markets. In particular, six out of seventeen regional governments (Andalusia, Aragon, Basque Country, Catalonia, Murcia and Valencia) have developed an extensive network of offices around the world over the last decade.

Market failures, such as asymmetric information or externalities, provide the economic justification for government involvement in export promotion. Spanish embassies, consulates and other national agencies are important sources of information and help to overcome market failures and enhance trade activities. However, regional governments consider that these Spanish institutions are not the best organisations to promote regional businesses abroad, mainly for small and medium size companies. This has led to the creation of alternative bodies that inform quickly and cheaply, and very often free of charge, about trade opportunities in foreign countries in order to promote exports. For instance, according to the Valencian agency (IVEX) these services include: "economic, legal and taxation information, finding and managing third party funds, searching for suitable partners and locations, assistance with administrative procedures,

* We would like to thank two anonymous referees for very helpful suggestions. Financial support from Ministerio de Ciencia y Tecnología (project SEC2003-05836/ECO), Generalitat Valenciana (project GV04B-070) and Agencia Valenciana de Ciencia y Tecnología (Grupos 03/151) is gratefully acknowledged. 
identification and initial selection of staff in the target area, and search for premises and available industrial land". So, their objectives are much more ambitious in promoting the internationalisation of the firms than those of embassies and consulates. In fact, diplomatic corps are engaged in more general bilateral affairs (political, military, cultural, etc.) while regional bodies focus exclusively on trade and investment.

The creation of export promotion agencies is considered a crucial instrument to boost the exports of small and medium-sized firms. However, until the past decade the bulk of empirical literature has failed to find a positive impact of these agencies on exports (Hogan et al. 1991, Gencturk and Kotabe 2001). Import substitution policies in developing countries and some of their management weaknesses have been noted as the main explanatory causes for this result. In the 1990s, as the strong anti-trade policy bias vanished, new empirical evidence suggested that the impact could be positive. ${ }^{1}$ More recently, Lederman et al. (2006) find that national export promotion agencies have on average a strong and statistically significant impact on exports. Rose (2007) in a seminal cross-country study linking foreign missions (embassies and consulates) to exports concludes that the presence of a foreign mission is associated with slightly higher exports.

In spite of the increasing amount of financial resources that regional governments spend on their 'foreign missions', there is no empirical evidence about the effect of these institutions on regional exports. The aim of this article is to analyse the effectiveness of Spanish regional foreign trade agencies by measuring their impact on regional exports.

\section{Methodology}

In this article, we estimate the effect of regional foreign trade agencies on exports using bilateral data on exports from each one of the 17 Spanish regions to a sample of 188 international markets. The natural framework to address this issue is the gravity model of bilateral trade. ${ }^{2}$ There are three main reasons that justify the use of this methodology in our research. Firstly, the gravity model has been extremely successful in explaining international trade flows. Secondly, the improved theoretical foundations of the gravity model make it consistent with a variety of leading theories on international trade. ${ }^{3}$ Finally, the fact that it allows us to consider geographical, cultural and political variables, in addition to economic variables, in the explanation of export flows. In its simplest formulation, the gravity equation states that bilateral trade flows depend positively on the economic size of both countries (regions), usually measured in terms of GDP, and negatively on the distance between them, in analogy to the Newtonian gravity equation. The idea is that GDP represents the productive capacity of the exporter and the absorptive capacity of the importer, while distance represents a proxy for transportation costs.

Gravity equations used in the international trade literature generally include, in addition to the aforementioned basic variables, dummies that aim to capture other factors influencing transaction costs. For example, either a common language, a common border, sharing member-

\footnotetext{
${ }^{1}$ See Lederman et al. (2006) for a review of the literature.

2 The early application of the gravity model to international trade was carried out by Tinbergen (1962); Pöyhönen (1963); and Linnemann (1966). Specialists in other fields had used the gravity model before international economists did. In particular, regional and urban economists used it as far back as 1946 (Zipf 1946).

${ }^{3}$ Despite its use in many early studies on international trade, the gravity model initially lacked theoretical foundations. However, nowadays it is backed up by sound theory. Anderson (1979) derives the gravity equation from a model with product differentiation. Bergstrand $(1985,1989)$ associates gravity equations to models of monopolistic competition. Helpman and Krugman (1985) justify the gravity equation in the framework of a model of trade with increasing returns to scale and product differentiation. Deardoff (1995) and Evenett and Keller (2002) show that gravity equations are consistent with most theoretical models of international trade. A recent structural specification of the gravity equation is provided by Anderson and Van Wincoop (2003).
} 
ship in an integration agreement, or the existence of colonial links reduces transaction costs, whereas the insularity or the landlocked status of a country or region increases them.

We estimate the following general equation:

$$
\begin{aligned}
\operatorname{Ln}\left(X_{i j t}\right)= & \beta_{0}+\beta_{1} \operatorname{Ln}\left(G D P_{i t}\right)+\beta_{2} \operatorname{Ln}\left(G D P_{j t}\right)+\beta_{3} \operatorname{Ln}\left(\operatorname{DIST}_{i j}\right) \\
& +\beta_{4} \text { EUEFTA }_{i j}+\beta_{5} \text { Lang }_{i j}+\beta_{6} \text { Border }_{i j}+\beta_{7} \text { Island }_{i j} \\
& +\beta_{8} \text { Iandlocked }_{i j}+\beta_{9} \text { EmbCon }_{j t}+\beta_{10} \text { RegAgen }_{i j t}+\lambda_{t}+u_{i j t}
\end{aligned}
$$

where $i$ denotes the exporter, $j$ denotes the importer, $t$ denotes time, and the variables are defined as:

$X_{i j t}$ represents exports from region $i$ to importer country $j$,

$\mathrm{GDP}_{i t}$ and $\mathrm{GDP}_{j t}$ refer to real GDP,

Dist $t_{i j}$ denotes the distance between $i$ and $j$,

$E U E F T A_{i j}$ is a binary dummy variable that takes the value of one if the trade partner is a member of the European Union or the European Free Trade Agreement,

Lang $_{i j}$ is a binary dummy variable which is unity if $i$ and $j$ have a common language,

Border $_{i j}$ is a binary dummy variable that takes the value of one when the trading partners share a border,

Island $_{i j}$ is the number of islands in the pair $(0,1$, or 2$)$,

Landlocked $_{i j}$ is the number of landlocked country-regions in the pair $(0,1$, or 2),

$E m b C_{j t}$ is the number of embassies and general consulates that Spain has in $j$,

$\operatorname{RegAgen}_{i j t}$ is the number of foreign trade agencies of region $i$ in country $j$,

$\lambda_{\mathrm{t}}$ are time dummies and

$u_{i j t}$ represents the omitted other influences on regional exports, assumed to be well behaved.

The main parameter of interest is $\beta_{10}$, which shows the marginal effect of an additional regional foreign mission on exports.

\section{Data}

We use data on exports in euros taken from all 17 Spanish regions to a sample of 188 trading entities (see Table A1) over the period 1995-2003. These series are taken from the 'Dirección General de Aduanas'. International trade flows have been deflated using the GDP deflators of the Spanish regions taken from the 'Regional Accounts database' (Instituto Nacional de Estadística). The independent variables are taken from different sources. The real GDP of Spanish regions come from the 'Regional Accounts database' (Instituto Nacional de Estadística). GDP in constant US dollars of the destinations are taken from the WDI (World Bank). GDP series are converted to euros using 1999 exchange rates. The distances (great-circle distances) as well as the instrumental variables are taken from Andrew Rose's website (http:// faculty.haas.berkeley.edu/arose). ${ }^{4}$ The data on the number of embassies and consulates come from the Spanish 'Ministerio de Asuntos Exteriores'. We exclude honorary consulates and consider an embassy and a separate chancery or consulate in the same city as just one. Data on the number of Spanish regional foreign trade agencies have been provided by the respective agencies.

\footnotetext{
${ }^{4}$ We are sincerely grateful to Andrew Rose for making his data public.
} 


\section{Empirical results}

We begin by estimating equation (1) excluding the variable of interest by OLS. This allows us to check whether the gravity equation works well and how it is affected by the inclusion of the number of foreign trade agencies. The results are presented in column 1 of Table 1 . The equation fits the data well, explaining almost three quarters of the variation in bilateral trade flows. Moreover, the gravity coefficients are economically and statistically significant with sensible interpretations: trade increases with the size of the economies and it decreases with distance. All the remaining estimated coefficients have the expected sign and are statistically significant at the 1 per cent level. In particular, the results indicate that, all else equal, exports drop by $55 \%[(\exp (-0.808)-1) * 100]$ if there are islands in the trading pair and by $66 \%$ in the case of landlocked areas. On the contrary, regions export $153 \%[(\exp (0.927)-1) * 100]$ more with EUEFTA countries. Similarly, sharing a common language or common border increases exports by $458 \%$ and $33 \%$, respectively. Finally, in line with Rose's results, embassies and consulates have a positive and significant but relatively small effect on exports $(11 \%)$.

Column 2 reports the results when the number of foreign agencies is added to the gravity equation. This variable is highly significant and displays a coefficient with the expected sign. In particular, the results indicate that, all else equal, having an export promotion agency increases regional exports by $74 \%$. This estimate seems large compared to the impact of embassies and consulates, but it is economically plausible. It is, for instance, much smaller than the effects of a regional trade agreement and a common language. In this estimation the coefficient of embassies is slightly reduced.

Table 1. Estimation results of the gravity equation (1). Dependent variable: log of regional exports

\begin{tabular}{|c|c|c|c|c|c|}
\hline & (1) & (2) & (3) & (4) & (5) \\
\hline RegAgencies $_{j}$ & & $\begin{array}{r}0.554 \\
(11.21)\end{array}$ & $\begin{array}{c}0.383 \\
(5.96)\end{array}$ & $\begin{array}{c}0.381 \\
(5.96)\end{array}$ & $\begin{array}{r}0.431 \\
(11.78)\end{array}$ \\
\hline $\mathrm{EmbCon}_{\mathrm{j}}$ & $\begin{array}{r}0.101 \\
(12.76)\end{array}$ & $\begin{array}{r}0.088 \\
(11.08)\end{array}$ & $\begin{array}{c}0.243 \\
(5.43)\end{array}$ & $\begin{array}{c}0.396 \\
(5.62)\end{array}$ & $\begin{array}{c}0.198 \\
(7.11)\end{array}$ \\
\hline Ln GDP ${ }_{i}$ & $\begin{array}{r}1.422 \\
(107.57)\end{array}$ & $\begin{array}{r}1.405 \\
(104.74)\end{array}$ & $\begin{array}{r}1.382 \\
(110.66)\end{array}$ & $\begin{array}{r}1.384 \\
(111.39)\end{array}$ & $\begin{array}{r}1.380 \\
(116.51)\end{array}$ \\
\hline $\operatorname{Ln} \operatorname{GDP}_{\mathrm{j}}$ & $\begin{array}{r}0.915 \\
(128.82)\end{array}$ & $\begin{array}{r}0.908 \\
(127.19)\end{array}$ & $\begin{array}{r}0.862 \\
(24.03)\end{array}$ & $\begin{array}{c}1.122 \\
(9.41)\end{array}$ & $\begin{array}{r}0.844 \\
(35.95)\end{array}$ \\
\hline Ln Distance ${ }_{i j}$ & $\begin{array}{r}-1.052 \\
(-44.23)\end{array}$ & $\begin{array}{r}-1.061 \\
(-44.57)\end{array}$ & $\begin{array}{c}-0.518 \\
(-4.45)\end{array}$ & & $\begin{array}{c}-0.507 \\
(-6.56)\end{array}$ \\
\hline EUEFTA $_{i j}$ & $\begin{array}{r}0.927 \\
(20.82)\end{array}$ & $\begin{array}{r}0.950 \\
(21.37)\end{array}$ & $\begin{array}{c}1.428 \\
(4.73)\end{array}$ & & $\begin{array}{r}1.769 \\
(12.14)\end{array}$ \\
\hline Language $_{i j}$ & $\begin{array}{r}1.720 \\
(44.58)\end{array}$ & $\begin{array}{r}1.714 \\
(44.41)\end{array}$ & $\begin{array}{c}1.272 \\
(5.24)\end{array}$ & & $\begin{array}{r}1.390 \\
(11.04)\end{array}$ \\
\hline Border $_{\mathrm{ij}}$ & $\begin{array}{c}0.286 \\
(2.32)\end{array}$ & $\begin{array}{c}0.113 \\
(0.78)\end{array}$ & $\begin{array}{c}0.243 \\
(1.02)\end{array}$ & $\begin{array}{c}0.245 \\
(1.03)\end{array}$ & $\begin{array}{r}0.223 \\
(1.77)\end{array}$ \\
\hline Island $_{i j}$ & $\begin{array}{r}-0.808 \\
(-25.03)\end{array}$ & $\begin{array}{r}-0.807 \\
(-25.05)\end{array}$ & $\begin{array}{r}-2.131 \\
(-62.45)\end{array}$ & $\begin{array}{r}-2.198 \\
(-63.93)\end{array}$ & $\begin{array}{r}-1.910 \\
(-44.91)\end{array}$ \\
\hline Landlocked $_{i j}$ & $\begin{array}{r}-1.075 \\
(-45.89)\end{array}$ & $\begin{array}{r}-1.077 \\
(-45.95)\end{array}$ & $\begin{array}{c}-0.146 \\
(-3.23)\end{array}$ & $\begin{array}{c}0.031 \\
(0.66)\end{array}$ & $\begin{array}{r}-0.512 \\
(-11.34)\end{array}$ \\
\hline Time dummies & Yes & Yes & Yes & Yes & No \\
\hline $\operatorname{Adj}-R^{2}$ & 0.72 & 0.72 & 0.67 & 0.44 & 0.80 \\
\hline No of observ. & 26,078 & 26,078 & 26,078 & 26,078 & 26,078 \\
\hline Estimation method & OLS & OLS & $\begin{array}{c}\text { PANEL } \\
\text { (R.E.) }\end{array}$ & $\begin{array}{c}\text { PANEL } \\
\text { (F.E.) }\end{array}$ & CYFE \\
\hline Sample period & 1995-2003 & 1995-2003 & 1995-2003 & 1995-2003 & 1995-2003 \\
\hline
\end{tabular}

Note: t-statistics in parentheses are robust to heteroscedasticity and autocorrelation. 
Columns 3 and 4 report panel estimations with importer individual effects (random and fixed effects). The Hausman test suggests the use of the fixed effect estimator. Nonetheless, the results for the parameter of interest are very similar for fixed-effect and random-effect estimations (0.38). It is worth noting that the fixed effect estimation leads to a reduction in the impact of regional agencies and a notable rise in the effect of embassies.

Anderson and Van Wincoop (2003) provide a theoretical foundation for the gravity model in which they point out that one must consider not only the trade resistance between any two countries (which are a function of distance, language, etc.), but also that different countries have a different general resistance to trade. In practice, this involves including country fixed effects when estimating the gravity model as a solution to the presence of such 'multilateral resistance' (column 4). More recently, Anderson and Van Wincoop (2004) note that separate country fixed effects should be included for each year in a panel framework as the multilateral resistance may change over time. Therefore, as a robustness check, we have also estimated the gravity equation including separate country fixed effects for each year (CYFE in the tables). The estimated coefficient for our variable of interest (column 5) is in line with those reported in column 3 and 4.

Since heavy exports to a country may induce Spanish regions to set up a foreign agency, there may be reverse causality from exports to trade agencies. Therefore, it is advisable to use instrumental variables. ${ }^{5}$ Unfortunately, we have not been able to find appropriate instruments with time variation. ${ }^{6}$ For this reason, we have considered a sub-sample covering the period 2002-2003, for which valid instruments exist. The results for this sample are reported in Table 2 . As was expected, the results using OLS (column 1) are quite similar to those found for the full sample period. The second column reports IV estimates using four variables as instruments for the number of foreign trade agencies that seek to measure the desirability of living in a destination country: the number of Condé-Nast destinations, the number of four-season hotels, the number of luxury hotels, and the number of Lonely Planet guides. ${ }^{7}$ Column 3 and 4 also report the results using an instrumental variable technique but in this case we account for the panel nature of the data set. Instrumental variables deliver a coefficient for the variable of interest that ranges from 0.63 to 0.79 and in all cases it is statistically significant at the 1 per cent level. Thus, the impact of foreign trade agencies on exports seems to be robust to the potential endogeneity problem.

In order to check whether the impact of the foreign trade agencies is widespread among the Spanish regions or, on the contrary, our results are driven by the experience of just some of them, we have estimated region-specific coefficients. Table 3 takes into account this issue for both samples. Focusing attention on the parameter of interest, the estimations without instrumental variables reveal that there are at least four regions with a positive and statistically significant coefficient at the 1 per cent level (Catalonia, Murcia, Basque Country, and Valencia). When we use country-year fixed effects this also happens for Aragon, although for this region the estimated coefficient is statistically significant at the 10 per cent level (column 3 ).

\footnotetext{
${ }^{5}$ In any case, it is worth noting that according to members of the Valencian Agency (IVEX) staff the decision to open a foreign trade office is not based on past exports. It is based mainly on the existence of market opportunities combined with barriers to entry in these markets because they are more unfamiliar than others (for instance, Japan and China are less familiar markets for Valencian exporters than those of the EU countries). If this is the case, there is not an endogeneity problem.

${ }^{6}$ We have used three series as potential instrumental variables: international tourist arrivals, military expenditure and ICRG composite risk ratio taken from the WDI. Other a priori potential instruments were not considered due to data availability problems.

${ }^{7}$ We have made proofs using the list of instruments suggested by Rose (2007) which are available in his web page. The selected instruments are the combination of the maximum number of instruments that are valid according to the Sargan test of overidentifying restrictions. It is worth noting that the variable 'embassies and consulates' has not been instrumented because, in contrast to Rose (2007) study, in a regional study of exports this variable should not be endogenous.
} 
Table 2. Estimation results of the gravity equation (1). Dependent variable: log of regional exports

\begin{tabular}{|c|c|c|c|c|}
\hline & (1) & (2) & (3) & (4) \\
\hline RegAgencies $_{\mathrm{j}}$ & $\begin{array}{c}0.444 \\
(4.60)\end{array}$ & $\begin{array}{c}0.795 \\
(2.67)\end{array}$ & $\begin{array}{c}0.654 \\
(2.72)\end{array}$ & $\begin{array}{c}0.631 \\
(2.66)\end{array}$ \\
\hline EmbCon $_{\mathrm{j}}$ & $\begin{array}{r}0.078 \\
(4.49)\end{array}$ & $\begin{array}{c}0.067 \\
(2.70)\end{array}$ & $\begin{array}{c}0.130 \\
(1.76)\end{array}$ & \\
\hline Ln GDP & $\begin{array}{r}1.350 \\
(46.62)\end{array}$ & $\begin{array}{r}1.343 \\
(40.59)\end{array}$ & $\begin{array}{r}1.324 \\
(49.64)\end{array}$ & $\begin{array}{c}1.331 \\
(50.66)\end{array}$ \\
\hline $\operatorname{Ln} \mathrm{GDP}_{\mathrm{j}}$ & $\begin{array}{c}0.900 \\
(61.07)\end{array}$ & $\begin{array}{r}0.895 \\
(53.54)\end{array}$ & $\begin{array}{r}0.867 \\
(17.26)\end{array}$ & $\begin{array}{l}2.428 \\
(1.83)\end{array}$ \\
\hline Ln Distance ${ }_{i j}$ & $\begin{array}{r}-1.053 \\
(-19.57)\end{array}$ & $\begin{array}{r}-1.059 \\
(-21.53)\end{array}$ & $\begin{array}{c}-0.676 \\
(-4.54)\end{array}$ & \\
\hline EUEFTA $_{\mathrm{ij}}$ & $\begin{array}{c}0.852 \\
(8.76)\end{array}$ & $\begin{array}{c}0.869 \\
(7.21)\end{array}$ & $\begin{array}{c}1.324 \\
(3.50)\end{array}$ & \\
\hline Language $_{i j}$ & $\begin{array}{r}1.518 \\
(19.15)\end{array}$ & $\begin{array}{r}1.517 \\
(15.78)\end{array}$ & $\begin{array}{c}1.228 \\
(4.04)\end{array}$ & \\
\hline Border $_{i j}$ & $\begin{array}{c}0.258 \\
(0.83)\end{array}$ & $\begin{array}{r}0.119 \\
(0.21)\end{array}$ & $\begin{array}{c}0.148 \\
(0.30)\end{array}$ & $\begin{array}{l}0.131 \\
(0.27)\end{array}$ \\
\hline Island $_{\mathrm{ij}}$ & $\begin{array}{r}-0.917 \\
(-12.88)\end{array}$ & $\begin{array}{r}-0.914 \\
(-14.71)\end{array}$ & $\begin{array}{c}-2.078 \\
(-30.02)\end{array}$ & $\begin{array}{c}-2.239 \\
(-31.76)\end{array}$ \\
\hline Landlocked $_{\mathrm{ij}}$ & $\begin{array}{r}-1.152 \\
(-22.02)\end{array}$ & $\begin{array}{c}-1.153 \\
(-24.33)\end{array}$ & $\begin{array}{l}-0.331 \\
(-3.92)\end{array}$ & $\begin{array}{c}0.120 \\
(1.24)\end{array}$ \\
\hline Time dummies & Yes & Yes & Yes & Yes \\
\hline $\operatorname{Adj}-R^{2}$ & 0.71 & 0.73 & 0.67 & 0.46 \\
\hline No of observ. & 5,593 & 5,593 & 5,593 & 5,593 \\
\hline Estimation method & OLS & IV & $\begin{array}{c}\text { PANEL-IV } \\
\text { R.E. }\end{array}$ & $\begin{array}{c}\text { PANEL-IV } \\
\text { F.E. }\end{array}$ \\
\hline Sargan test (D.F.) & & $7.14(3)$ & & $4.00(3)$ \\
\hline Sample period & $2002-2003$ & $2002-2003$ & $2002-2003$ & 2002-2003 \\
\hline
\end{tabular}

Note: $\mathrm{t}$-statistics in parentheses are robust to heteroscedasticity and autocorrelation. In the estimations with Instrumental Variables (IV), the number of Condé-Nast destinations, the number of four-season hotels, the number of luxury hotels, and the number of Lonely Planet guides are used as an instrument for the number of agencies.

However, using instrumental variables we obtain a clear reduction in the significance levels, the coefficient for Catalonia not being statistically significant at conventional levels in any case, although it is near the 10 per cent level. Taking all the results together, we find that the Basque Country and Murcia show the greatest impact of their respective trade agencies on exports. At the opposite end of the spectrum, Andalusia does not show a statistically significant positive effect.

\section{Conclusion}

In this short article we have estimated the effect of Spanish regional trade agencies on exports. Using the gravity equation of bilateral trade we have found that regional agencies boost exports even after controlling for potential endogeneity problems. The magnitude of this effect is larger than the impact of national embassies and consulates. This result is not surprising. Diplomatic corps are engaged in bilateral affairs at a national level (Spain in our case) whereas regional bodies focus exclusively on promoting trade for firms located in its specific territory. Finally, the region-by-region analysis shows that the effect is neither widespread nor uniform across regions. 
Table 3. Estimation results of the gravity equation (1) by regions

\begin{tabular}{|c|c|c|c|c|c|c|c|}
\hline & (1) & (2) & (3) & (4) & (5) & (6) & (7) \\
\hline AgenciesAndalusia & $\begin{array}{l}-0.203 \\
(-1.10)\end{array}$ & $\begin{array}{l}-0.531 \\
(-2.00)\end{array}$ & $\begin{array}{l}-0.553 \\
(-5.08)\end{array}$ & $\begin{array}{l}-0.123 \\
(-0.58)\end{array}$ & $\begin{array}{l}-0.998 \\
(-1.00)\end{array}$ & $\begin{array}{l}-1.132 \\
(-1.40)\end{array}$ & $\begin{array}{l}-1.165 \\
(-1.46)\end{array}$ \\
\hline AgenciesArargon & $\begin{array}{l}-0.112 \\
(-0.59)\end{array}$ & $\begin{array}{c}0.055 \\
(0.25)\end{array}$ & $\begin{array}{c}0.171 \\
(1.89)\end{array}$ & $\begin{array}{l}-0.692 \\
(-1.37)\end{array}$ & $\begin{array}{c}1.454 \\
(1.33)\end{array}$ & $\begin{array}{c}1.103 \\
(1.25)\end{array}$ & $\begin{array}{c}1.042 \\
(1.20)\end{array}$ \\
\hline AgenciesCatalonia & $\begin{array}{c}0.634 \\
(7.96)\end{array}$ & $\begin{array}{c}0.364 \\
(4.04)\end{array}$ & $\begin{array}{c}0.414 \\
(7.86)\end{array}$ & $\begin{array}{c}0.608 \\
(3.75)\end{array}$ & $\begin{array}{c}0.492 \\
(1.56)\end{array}$ & $\begin{array}{c}0.414 \\
(1.64)\end{array}$ & $\begin{array}{c}0.398 \\
(1.60)\end{array}$ \\
\hline AgenciesMurcia & $\begin{array}{r}0.837 \\
(6.12)\end{array}$ & $\begin{array}{c}0.552 \\
(3.38)\end{array}$ & $\begin{array}{c}0.624 \\
(5.86)\end{array}$ & $\begin{array}{c}0.694 \\
(3.48)\end{array}$ & $\begin{array}{c}1.022 \\
(1.75)\end{array}$ & $\begin{array}{c}0.896 \\
(1.92)\end{array}$ & $\begin{array}{r}0.891 \\
(1.93)\end{array}$ \\
\hline AgenciesBasqueCountry & $\begin{array}{r}0.842 \\
(9.32)\end{array}$ & $\begin{array}{c}0.831 \\
(4.56)\end{array}$ & $\begin{array}{r}0.867 \\
(14.23)\end{array}$ & $\begin{array}{c}0.838 \\
(4.75)\end{array}$ & $\begin{array}{l}1.325 \\
(2.08)\end{array}$ & $\begin{array}{l}1.107 \\
(2.16)\end{array}$ & $\begin{array}{c}1.087 \\
(2.16)\end{array}$ \\
\hline AgenciesValencia & $\begin{array}{c}0.442 \\
(6.48)\end{array}$ & $\begin{array}{c}0.384 \\
(2.90)\end{array}$ & $\begin{array}{r}0.411 \\
(8.16)\end{array}$ & $\begin{array}{c}0.345 \\
(2.55)\end{array}$ & $\begin{array}{c}0.651 \\
(1.45)\end{array}$ & $\begin{array}{c}0.620 \\
(1.70)\end{array}$ & $\begin{array}{c}0.612 \\
(1.70)\end{array}$ \\
\hline $\mathrm{EmbCon}_{\mathrm{j}}$ & $\begin{array}{r}0.089 \\
(11.15)\end{array}$ & $\begin{array}{c}0.394 \\
(5.58)\end{array}$ & $\begin{array}{l}0.198 \\
(7.15)\end{array}$ & $\begin{array}{c}0.078 \\
(4.53)\end{array}$ & $\begin{array}{c}0.068 \\
(2.72)\end{array}$ & $\begin{array}{c}0.132 \\
(1.71)\end{array}$ & \\
\hline $\operatorname{Ln~GDP}_{i}$ & $\begin{array}{l}1.405 \\
(103.3)\end{array}$ & $\begin{array}{r}1.386 \\
(110.63)\end{array}$ & $\begin{array}{r}1.382 \\
(115.04)\end{array}$ & $\begin{array}{r}1.355 \\
(45.72)\end{array}$ & $\begin{array}{r}1.365 \\
(40.55)\end{array}$ & $\begin{array}{r}1.343 \\
(49.61)\end{array}$ & $\begin{array}{r}1.349 \\
(50.50)\end{array}$ \\
\hline $\operatorname{Ln} \mathrm{GDP}_{\mathrm{j}}$ & $\begin{array}{r}0.908 \\
(127.09)\end{array}$ & $\begin{array}{c}1.120 \\
(9.39)\end{array}$ & $\begin{array}{r}0.844 \\
(35.94)\end{array}$ & $\begin{array}{r}0.901 \\
(60.93)\end{array}$ & $\begin{array}{r}0.900 \\
(53.72)\end{array}$ & $\begin{array}{r}0.872 \\
(16.72)\end{array}$ & $\begin{array}{c}2.439 \\
(1.83)\end{array}$ \\
\hline Ln Distance $_{i j}$ & $\begin{array}{r}-1.060 \\
(-44.55)\end{array}$ & & $\begin{array}{l}-0.507 \\
(-6.57)\end{array}$ & $\begin{array}{r}-1.052 \\
(-19.57)\end{array}$ & $\begin{array}{r}-1.059 \\
(-21.51)\end{array}$ & $\begin{array}{l}-0.671 \\
(-4.34)\end{array}$ & \\
\hline EUEFTA $_{\mathrm{ij}}$ & $\begin{array}{r}0.944 \\
(21.21)\end{array}$ & & $\begin{array}{r}1.768 \\
(12.13)\end{array}$ & $\begin{array}{c}0.838 \\
(8.59)\end{array}$ & $\begin{array}{c}0.853 \\
(6.99)\end{array}$ & $\begin{array}{c}1.314 \\
(3.35)\end{array}$ & \\
\hline Language $_{i j}$ & $\begin{array}{r}1.721 \\
(44.43)\end{array}$ & & $\begin{array}{r}1.388 \\
(11.03)\end{array}$ & $\begin{array}{r}1.531 \\
(19.26)\end{array}$ & $\begin{array}{r}1.511 \\
(15.59)\end{array}$ & $\begin{array}{r}1.221 \\
(3.88)\end{array}$ & \\
\hline Border $_{i j}$ & $\begin{array}{c}0.095 \\
(0.63)\end{array}$ & $\begin{array}{r}0.239 \\
(1.00)\end{array}$ & $\begin{array}{r}0.215 \\
(1.69)\end{array}$ & $\begin{array}{c}0.300 \\
(0.91)\end{array}$ & $\begin{array}{c}0.069 \\
(0.12)\end{array}$ & $\begin{array}{c}0.123 \\
(0.24)\end{array}$ & $\begin{array}{r}0.110 \\
(0.22)\end{array}$ \\
\hline Island $_{i j}$ & $\begin{array}{r}-0.808 \\
(-25.07)\end{array}$ & $\begin{array}{r}-2.197 \\
(-63.92)\end{array}$ & $\begin{array}{r}-1.909 \\
(-44.87)\end{array}$ & $\begin{array}{r}-0.918 \\
(-12.89)\end{array}$ & $\begin{array}{r}-0.910 \\
(-14.60)\end{array}$ & $\begin{array}{c}-2.089 \\
(-30.12)\end{array}$ & $\begin{array}{r}-2.239 \\
(-31.72)\end{array}$ \\
\hline Landlooked $_{\mathrm{ij}}$ & $\begin{array}{r}-1.077 \\
(-45.94)\end{array}$ & $\begin{array}{c}0.031 \\
(0.65)\end{array}$ & $\begin{array}{r}-0.512 \\
(-11.34)\end{array}$ & $\begin{array}{c}-1.152 \\
(-22.01)\end{array}$ & $\begin{array}{r}-1.149 \\
(-24.19)\end{array}$ & $\begin{array}{c}-0.309 \\
(-3.63)\end{array}$ & $\begin{array}{r}0.115 \\
(1.18)\end{array}$ \\
\hline Time dummies & Yes & Yes & No & Yes & Yes & Yes & Yes \\
\hline Adj- $R^{2}$ & 0.72 & 0.44 & 0.80 & 0.72 & 0.71 & 0.67 & 0.46 \\
\hline Sargan test (D.F.) & & & & & 14.07 (18) & & 14.07 (18) \\
\hline No of observations & 24,666 & 24,666 & 24,666 & 5,593 & 5,593 & 5,593 & 5,593 \\
\hline Estimation method & OLS & $\begin{array}{c}\text { PANEL } \\
\text { (F.E.) }\end{array}$ & CYFE & OLS & IV & $\begin{array}{l}\text { PANEL } \\
\text { IV (R.E.) }\end{array}$ & $\begin{array}{l}\text { PANEL IV } \\
\text { (F.E.) }\end{array}$ \\
\hline Sample period & 1995-03 & 1995-03 & 1995-03 & $2002-03$ & $2002-03$ & $2002-03$ & $2002-03$ \\
\hline
\end{tabular}

Note: t-statistics in parentheses are robust to heteroscedasticity and autocorrelation.

\section{References}

Anderson JE (1979) A theoretical foundation to the gravity equation. American Economic Review 69: 106-116

Anderson JE, Van Wincoop E (2003) Gravity with gravitas: A solution to the border puzzle. American Economic Review 93: 170-92

Anderson JE, Van Wincoop E (2004) Trade costs. Journal of Economic Literature 42: 691-741

Bergstrand JH (1985) The gravity equation in international trade: Some microeconomic foundations and empirical evidence. Review of Economics and Statistics 67: 474-481

Bergstrand JH (1989) The generalised gravity equation, monopolistic competition, and the factor proportions theory in international trade. Review of Economics and Statistics 71: 143-153

Deardoff AV (1995) Determinants of bilateral trade: Does gravity work in a neoclassic world? NBER Working Paper No 5377

Evenett SJ, Keller W (2002) On theories explaining the success of the gravity equation. Journal of Political Economy 110: $281-316$ 
Gencturk E, Kotabe M (2001) The effect of export assistance program usage on export performance: A contingency explanation. Journal of International Marketing 9: 51-72

Helpman E, Krugman P (1985) Market structure and foreign trade. Increasing returns, imperfect competition, and the international economy. The MIT press, Cambridge

Hogan P, Keesing D, Singer A (1991) The role of support services in expanding manufacturing exports in developing countries. Economic Development Institute seminar series, World Bank, Washington, D.C.

Lederman D, Olarreaga M, Payton L (2006) Export promotion agencies: What works and what doesn't. World Bank Policy Research Working Paper No 4044, November

Linnemann H (1966) An econometric study of international trade flows. North-Holland, Amsterdam

Pöyhönen P (1963) A tentative model for the volume of trade between countries. Weltwirtschaftliches Archiv 90: 93-99

Rose A (2007) The foreign service and foreign trade: Embassies as export promotion. The World Economy 30: 22-38

Tinbergen J (1962) An analysis of world trade flows. In: Tinbergen J (ed) Shaping the world economy. The Twentieth Century Fund, New York

Zipf GK (1946) The $\mathrm{P}^{1} \mathrm{P}^{2} / \mathrm{D}$ hypothesis: On the intercity movement of persons. American Sociological Review 11: $677-686$

Table A1. Export destinations

\begin{tabular}{|c|c|c|c|}
\hline Afghanistan & Albania & Algeria & American Samoa \\
\hline Angola & Antigua and Barbuda & Argentina & Armenia \\
\hline Aruba & Australia & Austria & Azerbaijan \\
\hline Bahamas & Bangladesh & Barbados & Bahrain \\
\hline Belize & Benin & Bhutan & Bosnia-Herzegovina \\
\hline Belarus & Belgium-Luxembourg & Bermudas & Bolivia \\
\hline Botswana & Brazil & Bulgaria & Burkina Faso \\
\hline Burundi & Cambodia & Cameroon & Canada \\
\hline Cape Verde & Central African Rep. & Chad & Chile \\
\hline China & Comoros & Congo Dem. Rep. & Costa Rica \\
\hline Colombia & Côte D'Ivoire & Croatia & Cuba \\
\hline Cyprus & Czech Republic & Denmark & Djibouti \\
\hline Dominica & Dominican Republic & Ecuador & Equatorial Guinea \\
\hline Egypt & El Salvador & Eritrea & Estonia \\
\hline Ethiopia & Faroe Island & Fiji & Finland \\
\hline France & French Polynesia & Gabon & Gambia \\
\hline Georgia & Germany & Ghana & Greece \\
\hline Greenland & Grenada & Guam & Guatemala \\
\hline Guinea & Guinea-Bissau & Guyana & Haiti \\
\hline Honduras & Hong Kong & Hungary & Iceland \\
\hline India & Indonesia & Iran & Iraq \\
\hline Ireland & Israel & Italy & Jamaica \\
\hline Japan & Jordan & Kazakhstan & Kenya \\
\hline Kiribati & Korea & Kuwait & Kyrgyz Republic \\
\hline Laos & Latvia & Lebanon & Lesotho \\
\hline Liberia & Libya & Lithuania & Macao \\
\hline Macedonia & Madagascar & Malaysia & Maldives \\
\hline Mali & Malawi & Malta & Mauritania \\
\hline Mauritius & Mexico & Moldova & Mongolia \\
\hline Morocco & Mozambique & Myanmar & Namibia \\
\hline Netherlands & Netherlands Antilles & New Caledonia & New Zealand \\
\hline Nicaragua & Niger & Nigeria & North Korea \\
\hline Norway & Oman & Pakistan & Panama \\
\hline Papua New Guinea & Paraguay & Peru & Philippines \\
\hline Poland & Portugal & Qatar & Romania \\
\hline Russia & Rwanda & Samoa & Sao Tome and Principe \\
\hline Saudi Arabia & Senegal & Serbia-Montenegro & Seychelles \\
\hline Sierra Leone & Singapore & Slovakia & Slovenia \\
\hline Solomon Islands & Somalia & South Africa & Sri Lanka \\
\hline Suriname & St. Lucia & St. Vincent & Sudan \\
\hline Swaziland & Sweden & Switzerland & Syria \\
\hline Tajikistan & Tanzania & Togo & Trinidad and Tobago \\
\hline Tunisia & Turkmenistan & Tuvalu & Thailand \\
\hline Tonga & Turkey & Uganda & Ukraine \\
\hline United Arab Emirates & United Kingdom & USA & Uruguay \\
\hline Uzbekistan & Vanuatu & Vietnam & Venezuela \\
\hline Yemen & Zambia & Zimbabwe & \\
\hline
\end{tabular}




\title{
Medición del impacto de la promoción de exportaciones regionales: el caso de España
}

\author{
Salvador Gil, Rafael Llorca, José A. Martínez Serrano
}

\begin{abstract}
Este artículo estima el efecto de las delegaciones comerciales regionales en el extranjero sobre las exportaciones utilizando el modelo de gravedad. Los resultados indican que las delegaciones regionales fomentan el comercio exterior. El impacto estimado parece ser mayor que el de las embajadas y consulados españoles. Por otro lado, un análisis desagregado muestra que este efecto no se distribuye uniformemente entre las regiones españolas.
\end{abstract}

\section{JEL classification: F14, R12}

Palabras clave: Exportación, delegaciones comerciales regionales en el extranjero, ecuación de gravedad, regiones españolas

要旨：本論では、重力モデルを使って、外国に設置されたスペインの地方貿 易振興局が輸出に及ぼす影響力を評価する。結果は、地方貿易振興局が貿易 を増大させることを示している。その推定効果は、スペイン大使館及び領事 館が貿易に及ぼす効果より大きいことを示す。さらに、非集計分析はこの影 響力がスペインの地方全体に均等に配分されているわけではないことを示す。 